\title{
Identification of the Problems Faced by Exceptional Children at Primary level in Khyber Pakhtunkhwa, Pakistan
}

\author{
Qaiser Suleman \\ M.Phil (Education), Institute of Education \& Research, Kohat University of Science \& \\ Technology, Khyber Pakhtunkhwa, (Pakistan) \\ Email: Look_for_reality@yahoo.com \\ Dr. Ishtiaq Hussain \\ Assistant Professor, Institute of Education \& Research, Kohat University of Science \& \\ Technology, Khyber Pakhtunkhwa, (Pakistan) \\ Email: dr.ishtiaqkust@gmail.com
}

\section{Zaib-Un-Nisa}

M.Phil (Education), Institute of Education \& Research, Kohat University of Science \& Technology, Khyber Pakhtunkhwa, (Pakistan)

\author{
Accepted: Jan 07, 2013 Published: March 03, 2013 \\ Doi:10.5296/ijhrs.v3i1.3402 URL: http://dx.doi.org/10.5296/ijhrs.v3i1.3402
}

\begin{abstract}
The purpose of the study was to identify the problems faced by exceptional children at primary level. All the government institutions for persons with disabilities in Khyber Pakhtunkhwa (Pakistan) constituted the population of the study. The study was delimited to physically handicapped students only. The study was further delimited to seven government institutions for persons with disabilities. From each institute, 5 teachers and 10 students were randomly selected. The study was descriptive in nature therefore a single questionnaire was developed as research instrument for the collection of data. After collection of the data, it was organized, tabulated, analyzed and interpreted. Percentage and chi square were applied for the analysis of data. After statistical analysis, the researchers concluded that curriculum was not designed to meet the needs of special children. Special children were not being taught according to Individualized Educational Programme (I.E.P). Basic educational facilities were not available. Therefore it was strongly recommended that special children should be taught through individualized educational programmes to strengthen their educational attainment. Curriculum should be designed according to the needs of the special children. Mobility aids i.e., crutches, wheelchairs, artificial limbs etc should be provided to each special education institution on priority basis.
\end{abstract}

Keywords: Identification, Problems, Exceptional Children, Primary Level 


\section{Introduction}

Educating and humanizing exceptional children is an exciting challenging and speedily changing career. The early history of special education is chiefly a history of separate school particularly for those children who were blind, deaf, physically handicapped or mentally retarded. The concept of the responsibility of state and community for the care of support of underprivileged and deprived is inherent in the basic teachings of Islam. To ensure the availability of facilities and services for handicapped is considered to be the stamp and characteristic of an educated and civilized society and a welfare state (Afzal, 1999).

Special education is generally defined as "when a child is unable to get information through the usual senses or unable to communicate himself or processes information too, slowly or took quickly, then the special modifications and adjustments are required (Kirl \& Callagber, 1989). Hence, the special needs and demands of the exceptional children have become the common responsibilities of regular education teachers, councilors, psychologists and other educational experts as well as parents and exceptional children. Both the family and the society in which special children reside are frequently the key of their growth and development. Parents of the special children depend on the three major factors, mature of the stress, the family's available resources and the way the family interprets the situation. Education is the developmental stepladder and all the able and disable children have the right to climb up this ladder and achieve their goals (Carl et. al, 1981). In one way it is regarded a profession with its own tools, techniques and research efforts, all focused on strengthening and improving instructional arrangements and methodologies for the assessment and fulfillment of the learning needs of exceptional children and adults. Special education is individually designed and planned and systematically supervised arrangement of physical surroundings, special equipments and materials, teaching methodologies and other interventions designed to help and facilitate exceptional children to achieve the maximum possible personal self-sufficiency and academic achievement (William \& Michael, 1984). An exceptional individual faces so many problems in his adequate adjustment due to his physical deformity and abnormality. As he is incapable to get involved himself in desired normal activities, this inability creates social problems i.e., lack of confidence, shyness and loneliness. He develops sensitivity that others have a low opinion about him due to his imperfection and an excessive exaggeration of this feeling in his mentality results in development of inferiority complex and self pity in him (Kausar, 2008).

The current paper was specially designed to identify the problems faced by exceptional children in their school setting. The findings of the study will be highly beneficial in preventing, diminishing or eliminating the problems in the fields of academics, locomotors, communication and adjustment of physically handicapped students.

\section{Review of Related Literature}

In Pakistan, physically handicapped children endure attitudinal inequalities and discriminations in their family setting and schools. They are not permitted to perform like 
other normal children; they are either neglected or over protected. They can not normally engage in recreation with siblings and thus they are prevented to participate in physical activities due to the fear that this may result in injury to their body or threat to their lives. Therefore those children are timid, physically weak and cannot move without support. They must be familiarized with the location of the schools, its buildings surroundings, path ways, room corridors, play grounds, toilets etc. Exceptional children especially physically handicapped children must be informed about the dangers and hazards in the school i.e., stairs, ditches, water channels, gutters and main wholes and all dangerous spots with in the premise. It is the responsibility of the mobility teachers and class teacher to familiarize the physically handicapped to the schools premises (Awan, 2000).

\section{Concept of Special Education}

Exceptional children require different teaching methodologies and techniques, instructional materials etc which can only be provided in special schools, to maintain student's attention" (Ornstein 1993). Special education is a field of education specially designed and planned to fulfill the educational needs and requirements of the exceptional children (Awan, 1988). Adams (1986) says that special education is concerned about to give special consideration and to provide exceptional opportunities and exceptional assistance to those individuals whose needs (whether by reason of special gifts or in the more generally excepted sense, significant handicaps, disorders or difficulties), while at the same time acknowledging their entitlement to maximum involvement in the social, political, cultural, moral and religious aspects of life which we all share. Ysseldyke \& Algozzine (1984) say "special education is and always has been a subsystem of general education that was designed and developed to provide educational experiences to those students who are regarded "different" or "abnormal". It is believed that these students have not, cannot or will not equip themselves from the educational experiences provided in regular or general classroom. A person is regarded as normal as along as he or she perform in such ways that the majority of others can do. Normality is a relative concept in that a persons' behavior may be viewed as normal or abnormal depending on the time and circumstances in which the behavior occurs. According to Shore (1986), special education is a specialized instruction for those children who possess educational disabilities based on a comprehensive evaluation. The instruction may take place in various situations, but should be accurately in line to their educational requirements and adapted to their learning mode. Furthermore, he also defines special education class as "instructional setting for a relatively small group of students having similar special educational requirements. They usually attend the class for most of the school day often called a self contained class". The Public Law (USA) defines special education as "specially designed instruction, at no cost to parents or guardians to meet the unique and special needs of handicapped children, including classroom instruction, instructions in physical education, home instruction and instruction in hospitals and institutions". According to Brennan (1985), special education is the amalgamation and combination of curriculum, teaching, support and learning environment required to meet the pupil's special educational needs in a proper and effective manner. It may form all or part of the pupil's curriculum, may be conveyed individually or in association with others, and may form all or part of his school 
career. Kasonde and Moberg (2001) define special education as "an individually planned, systematically implemented and carefully evaluated instruction to assist students who require additional support in learning. Coveys (1992) stated that special education train and educate children to become useful, productive and effective members of the community with the help of continuous improvement, innovation and refinement.

\section{The Aims of Special Education}

According to Yousaf (1978), the aims of special education for handicapped are:

1. To develop and enable the individual to function as effective and useful as possible with in their own atmosphere. In addition, they should be trained for self help and make them socially acceptable, to equip them with the norms of cleanliness, good speech and good manners etc.

2. To impart knowledge to assist them in every day of life, to enable them to read sign boards, to write the names. Buy or selling the articles, social sight vocabulary can be organized in Urdu or Sindhi version for teaching.

3. To launch vocational and job oriented training to make rehabilitation possible. So that they become able to adopt an occupation and earn livelihood for themselves.

4. To develop their overall personality so that they may enable to incorporate and adjust themselves into their own society.

5. To develop and promote spiritual, physical and mental growth of exceptional children.

6. To make possible contributions to their community.

\section{Exceptional Children}

It is fact and reality that every child possesses specific potentials as well as his own responsibilities. Therefore all children are unique and need attention individually to develop their potential fully. But some children are exceptional and do not require the same amount of attention. They need a special attention and these children are known as special children. According to Kausar (2008), all children show dissimilarities from one another in terms of their physical characteristics and learning abilities. The dissimilarities in most children are relatively small so that they can be benefited from general education programmes. Some children differ physically, mentally socially and educationally from normal children. These children are known as "Exceptional Children" and they require special attention in a special manner for their proper adjustment. Heward (2003) defined exceptional children as "the physical characteristics or learning capabilities of some children differ from the normal to such an extent that they need an individualized programme of special education and related services to fully benefit from education". Exceptional children do not acquire proper physical environment and motivation in regular classroom work, as they require special and unique treatment due to their disability. "Accessibility and convenience guidelines are readily available at Special Education School" (Roger et al., 2007). According to Hallahan and Kauffman (1986) the special children are different in some way from the average children. In more simple words, such children may have problems or special abilities in thinking, hearing, seeing, speaking, moving or socializing. More often than not such children have a combination of special abilities or disabilities. 
Harring and McCormic (1986) explained the word exceptional as "a label for children or individuals with disabilities and impairments as well as for the gifted and talented". According to Hallahan and Kauffman (1978), most exceptional individuals have a disability and they are often known as "handicapped" in laws, rules and daily discussions. They further differentiate disability from handicap in such a way that "a disability is an incapability to do something, a diminished ability to perform in a definite way. On the other hand, a handicap is a disadvantage imposed on a child or an individual. A disability may or may not be a handicap, depending on the conditions. Similarly a handicap may or may not be caused by disability. According to Hallahan \& Kauffrnen (1997), the physically exceptional persons either orthopeadically or neurologically impaired have to adjust with their own disabilities as well as their social environment. In fact they have to suffer a double burden, social handicap and actual physical loss. Physically disabled individuals are frequently started at, teased, rejected socially or treated unsympathetically. It is not really surprising, then physically disabled individuals must fight two battles i.e., the battle to overcome the limitations which are imposed by their physical conditions and the battle to be accepted by others.

\section{Classification of Special Children Visual Impairment}

Those individuals whose eyesight are very weak and are not able to educate in normal schools and require devices and special training for their education are called individuals with visual impairments (Akber, 1989). Visually Impaired people use their hearing capability in social contacts but their social contacts remain uncertain and frustrated. They feel rejected. If blind individuals are praised and appreciated, then their academic score increases. A study also recommends that sufferings or difficulties of a visually impaired individual are due to social pressure not because of blindness. Research studies conducted on the behavior of blind individual show that blindness does not cause psychological or developmental disturbance but the disturbance depends upon the experience the blind persons which is received in their environment (Iqbal, 1995). According to Barrage a visually handicapped child is one whose visual impairments impede with his optimal learning and achievements, unless adaptations or modifications are made in the methods of presenting learning experiences, the nature of the materials used, and or in the learning environment (William \& Michael, 1984).

\section{Hearing Impairment}

Those individuals who are unable to hear and not able to educate them in normal schools and require special devices training for their education are called individuals with hearing impairments. According to Orlansky (1979) a deaf person is one whose hearing is disabled to an extent that impedes in understanding the speech through the ear alone with or without the use of a hearing device. On the other hand, a hard of hearing individual is one whose hearing is disabled to an extent that causes difficulties but not preclude the understanding of speech through the ear alone, with or without the use of hearing device. According to Iqbal (1995), the higher the loss, the higher will be the degree of difficulty of communication or interaction. The behavior of the hearing impaired is the result of isolation because of difficulty in conceiving emotions of their peers, therefore deaf lack maturity of 
social interaction. Deafness from early childhood creates stress and tension, the influence of which can be perceived in his behavior.

\section{Mental Retardation}

Mental retardation is a hereditary disorder manifested in significantly below average overall intellectual functioning and deficits in adaptive behaviour. Mental retardation is a definite state of functioning that initiates in childhood and is characterized by decreased intelligence and adaptive skills and also is the most common developmental disorder (Bregman, 1991). According to American Association on Mental Retardation (1992), mental retardation refers to substantial limitations or restrictions in present functioning. It is characterized by significantly subaverage intellectual functioning, existing alongside with associated limitations in two or more of applicable adaptive skill areas i.e., self-care, communication, home living, community use, social skills, self-direction, health and safety, functional academics, leisure, and work. Mental retardation manifests before the age of 18 (Luckasson et al., 1992). The American Association on Mental Retardation 2002 manual defines mental retardation as "a disability characterized by significant limitations or restrictions both in intellectual functioning and in adaptive behavior as expressed in conceptual, social, and practical adaptive skills. This disability begins before the age of 18 " (Luckasson et al., 2002).

\section{Physical Handicapped}

A physically handicapped child can be defined as one suffering from any continuing disability of body, intellect or personality which likely to interfere with his normal growth, development or capacity to learn. The majority of handicap fall in to the categories of physical, mental and emotional. Shah and Bano (2002) conducted a research study on the emotional problems of physically handicapped children and concluded that "physically handicapped children appear to be immature, have poor adjustment, difficulties in reaching out to the world and towards others, tendency to withdraw, are obviously aggressive and have anxiety". Noel (2010) found that a physical handicap is a physical or mental disability makes participation of a child more difficult in certain common daily activities. Physically handicapped children are in all shades, shapes and sizes. Some handicaps can occur because of a disability such as deafness, blindness or injuries that can cause paralysis or amputations. Noel (2010) also stated that some physical handicaps are not always an obstruction or impediment to someone's daily life.

\section{Statement of the Problem}

The current research study basically designed to identify the problems faced by exceptional children in Khyber Pakhtunkhwa. Therefore the statement of the problem was entitled as "Identification of the Problems Faced by Exceptional Children at Primary level in Khyber Pakhtunkhwa, Pakistan”.

\section{Objectives of the Study}

The objectives of the study were: 


\section{Mll Macrothink}

International Journal of Human Resource Studies

ISSN 2162-3058

2013, Vol. 3, No. 1

a) to explore the problems faced by physically handicapped students at special education centers in Khyber Pakhtunkhwa and

b) to make workable recommendations for the solution of problems of physically handicapped students at special education centers in Khyber Pakhtunkhwa.

\section{Research Methodology}

\section{Population}

All the teachers and students working and studying at special education institutions at primary level in Khyber Pakhtunkhwa (Pakistan) constituted the population of the study.

\section{Delimitations of the Study}

The study was delimited to the students who were physically handicapped at Special Education Institutions in Khyber Pakhtunkhwa. The study was further delimited to the selected seven institutions for persons with disabilities.

\section{Sample and Sampling Technique}

In order to ensure adequate representation of the population, only five teachers and ten students from each Special Education Institute at primary level were selected through simple random sampling technique. In this way, 35 teachers and 70 physically handicapped students were selected randomly from these institutions.

\section{Research Instrumentation}

It was a descriptive study and a self-developed questionnaire was used as research instrument for the collection of data. The questionnaire was composed of two sections. Section A of the questionnaire was designed on five point likert's scale as; SA (Strongly agree), A (Agree), UN (Undecided), DA (Disagree) and SDA (Strongly disagree). The section B was composed of open ended questions to explore the views of teachers and students about the problems faced by physically handicapped students.

\section{Pilot Testing}

The authentic results of the research study depend upon the effectiveness and authentication of research instruments. That is why the research instrument has the most crucial position in the research study. Therefore, pilot testing was conducted to eliminate the weaknesses, misconceptions and ambiguities of the questions in questionnaire. After conduction of pilot testing, questionnaire was revised and modified. Final version of the questionnaire was developed and prepared in the light of suggestions given by the experts.

\section{Validity and Reliability}

It is a reality that accurate results depend upon the reliability and accuracy of the research instrument. That is why it was very important to ensure the reliability and accuracy of the research instruments. According to Gay (2005) \& Masrur (2003), reliability is the degree of consistency that an instrument or data collection procedure demonstrates while validity is the quality of the collection procedure of the data that enables it to measure what it intends to 
measure. Validity was checked by five experts in the field of education. Cronbach's alpha was used to calculate the reliability of questionnaire. The reliability coefficient was found to be 0.84 of the questionnaire.

\section{Data Collection}

The researchers personally visited to the sample Special Education Institutions and distributed the questionnaires among the participants for collection of data. The researchers distributed 105 questionnaires among the sample subjects and received 105 responses i.e., $100 \%$. After great efforts and personal contacts, it was possible to collect appropriate number of responses from the respective respondents.

\section{Data Analysis}

After collection of data, it was organized, tabulated, analyzed and interpreted. Percentage and chi-square were applied for the statistical analysis of the data. The responses of the open ended questions were tabulated and analyzed on the basis of frequencies and percentage.

\section{Interpretation of Data and Results}

The study was basically designed to identify the problems faced by exceptional children at their special education centers. Data was collected through self-developed questionnaire. Then it was organized, tabulated, analyzed and interpreted. Percentage and chi square were applied for the statistical treatment of the data. The whole process is explained in detail as follow:

Table 01: Transport facility is available for physically handicapped students from government side.

\begin{tabular}{|c|c|c|c|c|c|c|c|c|}
\hline Respondents & $\mathbf{S A}$ & $\mathbf{A}$ & UD & DA & SDA & Total & $\chi^{2}$ & p-value \\
\hline Teachers & $\begin{array}{c}04 \\
(11.4 \%)\end{array}$ & $\begin{array}{c}05 \\
(14.5 \%)\end{array}$ & $\begin{array}{c}02 \\
(05.8 \%)\end{array}$ & $\begin{array}{c}15 \\
(43.5 \%)\end{array}$ & $\begin{array}{c}09 \\
(26.1 \%)\end{array}$ & 35 & & \\
\hline Students & $\begin{array}{c}06 \\
(08.4 \%)\end{array}$ & $\begin{array}{c}02 \\
(02.4 \%)\end{array}$ & $\begin{array}{c}05 \\
(07.0 \%)\end{array}$ & $\begin{array}{c}38 \\
(53.2 \%)\end{array}$ & $\begin{array}{c}19 \\
(26.6 \%)\end{array}$ & 70 & 5.46 & .24 \\
\hline Total & 10 & 07 & 07 & 53 & 28 & 105 & & \\
\hline
\end{tabular}

Table 1 depicts that the calculated value of $\chi^{2}$ was found to be 5.46 which is statistically non-significant because it is less than the critical table value of $\chi^{2}$ at 0.05 level. It clearly shows that both teachers and students have the same opinions about the statement. They both disagreed to the statement "transport facility is available for physically handicapped students for government side". 
Table 02: School building is large enough to provide facilities (like, more classrooms, libraries, laboratories etc) for physically handicapped students.

\begin{tabular}{|c|c|c|c|c|c|c|c|c|}
\hline Respondents & $\mathbf{S A}$ & $\mathbf{A}$ & UD & DA & SDA & Total & $\chi^{2}$ & p-value \\
\hline Teachers & $\begin{array}{c}04 \\
(11.6 \%)\end{array}$ & $\begin{array}{c}06 \\
(17.4 \%)\end{array}$ & $\begin{array}{c}02 \\
(05.8 \%)\end{array}$ & $\begin{array}{c}18 \\
(52.2 \%)\end{array}$ & $\begin{array}{c}05 \\
(43.5 \%)\end{array}$ & 35 & \multirow{3}{*}{1.05} & \multirow{3}{*}{.90} \\
\hline Students & $\begin{array}{c}09 \\
(12.6 \%)\end{array}$ & $\begin{array}{c}09 \\
(12.6 \%)\end{array}$ & $\begin{array}{c}04 \\
(05.6 \%)\end{array}$ & $\begin{array}{c}33 \\
(46.2 \%)\end{array}$ & $\begin{array}{c}15 \\
(21.0 \%)\end{array}$ & 70 & & \\
\hline Total & 13 & 15 & 06 & 51 & 20 & 105 & & \\
\hline
\end{tabular}

Non-Significant $(p>0.05) \quad$ df $=4$

table value $\chi^{2}$ at 0.05 level $=9.488$

Table 2 depicts that the computed value of $\chi^{2}$ was found to be 1.05 which is statistically non-significant as it is less than the critical table value of $\chi^{2}$ at 0.05 level. It explicitly shows that both teachers and students possess similar opinions about the statement. They both disagreed to the statement "School building is large enough to provide facilities (like more classrooms, libraries, laboratories etc) for physically handicapped students".

Table 03: Well equipped library is present in the school.

\begin{tabular}{|c|c|c|c|c|c|c|c|c|}
\hline Respondents & $\mathbf{S A}$ & $\mathbf{A}$ & UD & DA & SDA & Total & $\chi^{2}$ & p-value \\
\hline Teachers & $\begin{array}{c}05 \\
(14.5 \%)\end{array}$ & $\begin{array}{c}04 \\
(11.6 \%)\end{array}$ & $\begin{array}{c}02 \\
(05.8 \%)\end{array}$ & $\begin{array}{c}21 \\
(60.9 \%)\end{array}$ & $\begin{array}{c}03 \\
(08.7 \%)\end{array}$ & 35 & \multirow{3}{*}{1.58} & \multirow{3}{*}{.81} \\
\hline Students & $\begin{array}{c}07 \\
(09.8 \%\end{array}$ & $\begin{array}{c}11 \\
(15.4 \%)\end{array}$ & $\begin{array}{c}05 \\
(07.0 \%)\end{array}$ & $\begin{array}{c}37 \\
(51.8 \%)\end{array}$ & $\begin{array}{c}10 \\
(14.0 \%)\end{array}$ & 70 & & \\
\hline Total & 12 & 15 & 07 & 58 & 13 & 105 & & \\
\hline
\end{tabular}

Non-Significant $(p>0.05) \quad$ df $=4$

table value $\chi^{2}$ at 0.05 level $=9.488$

Table 3 indicates that the calculated value of $\chi^{2}$ was found to be 1.58 which is statistically non-significant because it is less than the critical table value of $\chi^{2}$ at 0.05 level. It undoubtedly shows that both teachers and students possess the same opinions about the statement. They both disagreed to the statement "Well equipped library is present in the school".

Table 04: Different cautionary signboards are displayed for students with disabilities.

\begin{tabular}{|c|c|c|c|c|c|c|c|c|}
\hline Respondents & $\mathbf{S A}$ & $\mathbf{A}$ & UD & DA & SDA & Total & $\chi^{2}$ & p-value \\
\hline Teachers & $\begin{array}{c}04 \\
(11.6 \%)\end{array}$ & $\begin{array}{c}09 \\
(26.1 \%)\end{array}$ & $\begin{array}{c}02 \\
(05.8 \%)\end{array}$ & $\begin{array}{c}17 \\
(49.3 \%)\end{array}$ & $\begin{array}{c}03 \\
(08.7 \%)\end{array}$ & 35 & & \\
\hline Students & $\begin{array}{c}02 \\
(02.8 \%) \\
\end{array}$ & $\begin{array}{c}09 \\
(12.6 \%) \\
\end{array}$ & $\begin{array}{c}11 \\
(15.4 \%) \\
\end{array}$ & $\begin{array}{c}29 \\
(40.6 \%) \\
\end{array}$ & $\begin{array}{c}19 \\
(26.6 \%) \\
\end{array}$ & 70 & $11.25 *$ & .02 \\
\hline Total & 06 & 18 & 13 & 46 & 22 & 105 & & \\
\hline
\end{tabular}


Table 4 illustrates that the calculated value of $\chi^{2}$ was found to be 11.25 which is statistically significant because it is greater than the critical table value of $\chi^{2}$ at 0.05 level. It clearly shows that teachers and students have slight different opinions about the statement. The opinions of the students are more negative as compared to the opinions of the teachers. But overall they both disagreed to the statement "Different cautionary signboards are displayed for students with disabilities".

Table 05: Mobility tools or aids (Wheelchairs, Crutches, and Artificial limbs etc) are available in the institution.

\begin{tabular}{|c|c|c|c|c|c|c|c|c|}
\hline Respondents & $\mathbf{S A}$ & $\mathbf{A}$ & UD & DA & SDA & Total & $\chi^{2}$ & p-value \\
\hline Teachers & $\begin{array}{c}05 \\
(14.5 \%)\end{array}$ & $\begin{array}{c}02 \\
(05.8 \%)\end{array}$ & $\begin{array}{c}03 \\
(08.7 \%)\end{array}$ & $\begin{array}{c}12 \\
(34.8 \%)\end{array}$ & $\begin{array}{c}13 \\
(37.7 \%)\end{array}$ & 35 & \multirow{3}{*}{0.89} & \multirow{3}{*}{.93} \\
\hline Students & $\begin{array}{c}12 \\
(16.8 \%)\end{array}$ & $\begin{array}{c}03 \\
(04.2 \%)\end{array}$ & $\begin{array}{c}05 \\
(07.0 \%)\end{array}$ & $\begin{array}{c}21 \\
(29.4 \%)\end{array}$ & $\begin{array}{c}33 \\
(46.2 \%)\end{array}$ & 70 & & \\
\hline Total & 17 & 05 & 08 & 33 & 46 & 105 & & \\
\hline
\end{tabular}

Non-Significant $(\mathrm{p}>\mathbf{0 . 0 5}) \quad \mathrm{df}=\mathbf{4}$

table value $\chi^{2}$ at 0.05 level $=9.488$

Table 5 depicts that the computed value of $\chi^{2}$ was found to be 0.89 which is statistically non-significant because it is less than the critical table value of $\chi^{2}$ at 0.05 level. It unambiguously shows that both teachers and students have the same opinions about the statement. They both disagreed to the statement "Mobility aids (Wheelchairs, Crutches and Artificial limbs etc) are available in the institution".

Table 06: Students' progress is reviewed monthly properly and fairly.

\begin{tabular}{|c|c|c|c|c|c|c|c|c|}
\hline Respondents & SA & $\mathbf{A}$ & UD & DA & SDA & Total & $\chi^{2}$ & p-value \\
\hline Teachers & $\begin{array}{c}03 \\
(08.7 \%)\end{array}$ & $\begin{array}{c}02 \\
(05.8 \%)\end{array}$ & $\begin{array}{c}02 \\
(05.8 \%)\end{array}$ & $\begin{array}{c}09 \\
(26.1 \%)\end{array}$ & $\begin{array}{c}19 \\
(55.1 \%)\end{array}$ & 35 & \multirow{3}{*}{8.32} & \multirow{3}{*}{.08} \\
\hline Students & $\begin{array}{c}12 \\
(16.8 \%) \\
\end{array}$ & $\begin{array}{c}13 \\
(18.2 \%) \\
\end{array}$ & $\begin{array}{c}06 \\
(08.4 \%) \\
\end{array}$ & $\begin{array}{c}19 \\
(26.6 \%) \\
\end{array}$ & $\begin{array}{c}20 \\
(28.0 \%) \\
\end{array}$ & 70 & & \\
\hline Total & 15 & 15 & 08 & 28 & 39 & 105 & & \\
\hline
\end{tabular}

Non-Significant $(p>0.05) \quad$ df $=4$

table value $\chi^{2}$ at 0.05 level $=9.488$

Table 6 indicates that the calculated value of $\chi^{2}$ was found to be 8.32 which is statistically non-significant as it is less than the critical table value of $\chi^{2}$ at 0.05 level. It shows that both teachers and students have the same opinions about the statement. They both disagreed to the statement "Students' progress is to be reviewed monthly properly and fairly". 
Table 07: Facility for physiotherapy is available in the institution.

\begin{tabular}{|c|c|c|c|c|c|c|c|c|}
\hline Respondents & $\mathbf{S A}$ & $\mathbf{A}$ & UD & DA & SDA & Total & $\chi^{2}$ & p-value \\
\hline Teachers & $\begin{array}{c}06 \\
(17.4 \%)\end{array}$ & $\begin{array}{c}08 \\
(23.2 \%)\end{array}$ & $\begin{array}{c}01 \\
(02.9 \%)\end{array}$ & $\begin{array}{c}13 \\
(37.7 \%)\end{array}$ & $\begin{array}{c}07 \\
(20.3 \%)\end{array}$ & 35 & & \\
\hline Students & $\begin{array}{c}03 \\
(04.2 \%) \\
\end{array}$ & $\begin{array}{c}05 \\
(07.0 \%) \\
\end{array}$ & $\begin{array}{c}11 \\
(15.4 \%) \\
\end{array}$ & $\begin{array}{c}20 \\
(28.0 \%)\end{array}$ & $\begin{array}{c}31 \\
(43.4 \%) \\
\end{array}$ & 70 & $16.89 *$ & .00 \\
\hline Total & 09 & 13 & 22 & 33 & 38 & 105 & & \\
\hline
\end{tabular}

*Significant $(\mathrm{p}<0.05) \quad \mathrm{df}=4 \quad$ table value $\chi^{2}$ at 0.05 level $=9.488$

Table 7 illustrates that the calculated value of $\chi^{2}$ was found to be 16.89 which is statistically significant because it is greater than the critical table value of $\chi^{2}$ at 0.05 level. It clearly indicates that teachers and students have slightly different views about the statement. The views of the students are more negative as compared to the views of teachers. But overall they both disagreed to the statement "Facility for physiotherapy is available in the institution".

Table 08: Parents prefer their children without a disability over their children with disability.

\begin{tabular}{|c|c|c|c|c|c|c|c|c|}
\hline Respondents & $\mathbf{S A}$ & $\mathbf{A}$ & UD & DA & SDA & Total & $\chi^{2}$ & p-value \\
\hline Teachers & $\begin{array}{c}09 \\
(26.1 \%)\end{array}$ & $\begin{array}{c}16 \\
(46.4 \%)\end{array}$ & $\begin{array}{c}04 \\
(11.6 \%)\end{array}$ & $\begin{array}{c}04 \\
(11.6 \%)\end{array}$ & $\begin{array}{c}02 \\
(05.8 \%)\end{array}$ & 35 & & \\
\hline Students & $\begin{array}{c}17 \\
(23.8 \%) \\
\end{array}$ & $\begin{array}{c}34 \\
(47.6 \%) \\
\end{array}$ & $\begin{array}{c}05 \\
(07.0 \%) \\
\end{array}$ & $\begin{array}{c}09 \\
(12.6 \%) \\
\end{array}$ & $\begin{array}{c}05 \\
(07.0 \%) \\
\end{array}$ & 70 & 0.67 & .96 \\
\hline Total & 26 & 50 & 09 & 13 & 07 & 105 & & \\
\hline
\end{tabular}

Table 8 illustrates that the calculated value of $\chi^{2}$ was found to be 0.67 which is statistically non-significant as it is less than the table value of $\chi^{2}$ at 0.05 level. It obviously indicates that both teachers and students possess similar opinions about the statement. They both agreed to the statement "Parents prefer their children without a disability over their children with disability".

Table 09: Students with special needs feel inferiority complex in society which causes their mental retardation.

\begin{tabular}{lllllllll}
\hline Respondents & SA & A & UD & DA & SDA & Total & $\chi^{2}$ & p-value \\
\hline
\end{tabular}




\begin{tabular}{|c|c|c|c|c|c|c|c|c|}
\hline Teachers & $\begin{array}{c}18 \\
(52.2 \%)\end{array}$ & $\begin{array}{c}11 \\
(31.9 \%)\end{array}$ & $\begin{array}{c}03 \\
(08.7 \%)\end{array}$ & $\begin{array}{c}02 \\
(05.8 \%)\end{array}$ & $\begin{array}{c}01 \\
(02.9 \%)\end{array}$ & 35 & \multirow{3}{*}{0.23} & \multirow{3}{*}{.99} \\
\hline Students & $\begin{array}{c}34 \\
(47.6 \%)\end{array}$ & $\begin{array}{c}25 \\
(35.0 \%)\end{array}$ & $\begin{array}{c}05 \\
(07.0 \%)\end{array}$ & $\begin{array}{c}04 \\
(08.4 \%)\end{array}$ & $\begin{array}{c}02 \\
(02.8 \%)\end{array}$ & 70 & & \\
\hline Total & 52 & 36 & 08 & 06 & 03 & 105 & & \\
\hline
\end{tabular}

Table 9 depicts that the calculated value of $\chi^{2}$ was found to be 0.23 which is statistically non-significant as it is less than the critical table value of $\chi^{2}$ at 0.05 level. It clearly elaborates that both teachers and students have the same opinions about the statement. They both agreed to the statement "Students with special needs feel inferiority complex in society which causes their mental retardation".

Table 10: Classrooms are arranged to provide the ease for special needs children.

\begin{tabular}{|c|c|c|c|c|c|c|c|c|}
\hline Respondents & $\mathbf{S A}$ & $\mathbf{A}$ & UD & DA & SDA & Total & $\chi^{2}$ & p-value \\
\hline Teachers & $\begin{array}{c}06 \\
(17.4 \%)\end{array}$ & $\begin{array}{c}07 \\
(20.3 \%)\end{array}$ & $\begin{array}{c}02 \\
(05.8 \%)\end{array}$ & $\begin{array}{c}13 \\
(37.7 \%)\end{array}$ & $\begin{array}{c}07 \\
(20.3 \%)\end{array}$ & 35 & \multirow{3}{*}{0.25} & \multirow{3}{*}{.99} \\
\hline Students & $\begin{array}{c}14 \\
(19.6 \%)\end{array}$ & $\begin{array}{c}13 \\
(18.2 \%)\end{array}$ & $\begin{array}{c}05 \\
(07.0 \%)\end{array}$ & $\begin{array}{c}24 \\
(33.6 \%)\end{array}$ & $\begin{array}{c}14 \\
(19.6 \%)\end{array}$ & 70 & & \\
\hline Total & 20 & 20 & 07 & 37 & 21 & 105 & & \\
\hline
\end{tabular}

Non-Significant $(p>0.05) \quad$ df $=4$

table value $\chi^{2}$ at 0.05 level $=9.488$

Table 10 shows that the computed value of $\chi^{2}$ was found to be 0.25 which is statistically non-significant because it is less than the critical table value of $\chi^{2}$ at 0.05 level. It explicitly indicates that both teachers and students have the same opinions about the statement. They both disagreed to the statement "Classrooms are arranged to provide the ease for special needs children".

Table 11: Curriculum is designed according to needs of exceptional children.

\begin{tabular}{|c|c|c|c|c|c|c|c|c|}
\hline Respondents & $\mathbf{S A}$ & $\mathbf{A}$ & UD & DA & SDA & Total & $\chi^{2}$ & p-value \\
\hline Teachers & $\begin{array}{c}04 \\
(11.6 \%)\end{array}$ & $\begin{array}{c}09 \\
(26.1 \%)\end{array}$ & $\begin{array}{c}03 \\
(08.7 \%)\end{array}$ & $\begin{array}{c}13 \\
(37.7 \%)\end{array}$ & $\begin{array}{c}06 \\
(17.4 \%)\end{array}$ & 35 & \multirow{3}{*}{1.28} & \multirow{3}{*}{.86} \\
\hline Students & $\begin{array}{c}09 \\
(12.6 \%)\end{array}$ & $\begin{array}{c}16 \\
(22.4 \%)\end{array}$ & $\begin{array}{c}04 \\
(05.6 \%)\end{array}$ & $\begin{array}{c}23 \\
(32.2 \%)\end{array}$ & $\begin{array}{c}18 \\
(25.2 \%)\end{array}$ & 70 & & \\
\hline Total & 13 & 25 & 07 & 36 & 24 & 105 & & \\
\hline
\end{tabular}

Non-Significant $(p>0.05) \quad$ df $=4$

table value $\chi^{2}$ at 0.05 level $=9.488$

Table 11 indicates that the computed value of $\chi^{2}$ was found to be 1.28 which is statistically non-significant as it is less than the critical table value of $\chi^{2}$ at 0.05 level. It clearly shows that both teachers and students have the same opinions about the statement. They both disagreed to the statement "Curriculum is designed according to the needs of exceptional children". 
Table 12: Teachers are skillful for handling students with special needs.

\begin{tabular}{|c|c|c|c|c|c|c|c|c|}
\hline Respondents & $\mathbf{S A}$ & $\mathbf{A}$ & UD & DA & SDA & Total & $\chi^{2}$ & p-value \\
\hline Teachers & $\begin{array}{c}05 \\
(14.5 \%)\end{array}$ & $\begin{array}{c}08 \\
(23.2 \%)\end{array}$ & $\begin{array}{c}03 \\
(08.7 \%)\end{array}$ & $\begin{array}{c}14 \\
(40.6 \%)\end{array}$ & $\begin{array}{c}05 \\
(14.5 \%)\end{array}$ & 35 & \multirow{3}{*}{0.51} & \multirow{3}{*}{.97} \\
\hline Students & $\begin{array}{c}12 \\
(16.8 \%) \\
\end{array}$ & $\begin{array}{c}15 \\
(21.0 \%)\end{array}$ & $\begin{array}{c}04 \\
(05.6 \%)\end{array}$ & $\begin{array}{c}30 \\
(42.0 \%)\end{array}$ & $\begin{array}{c}09 \\
(12.6 \%)\end{array}$ & 70 & & \\
\hline Total & 17 & 23 & 07 & 44 & 14 & 105 & & \\
\hline
\end{tabular}

Table 12 illustrates that the calculated value of $\chi^{2}$ was found to be 0.51 which is statistically non-significant as it is less than the critical table value of $\chi^{2}$ at 0.05 level. It plainly shows that both teachers and students have the same opinions about the statement. They both disagreed to the statement "Teachers are skillful for handling students with special needs".

Table 13: Examination system is encouraging for students with special needs.

\begin{tabular}{|c|c|c|c|c|c|c|c|c|}
\hline Respondents & $\mathbf{S A}$ & $\mathbf{A}$ & UD & DA & SDA & Total & $\chi^{2}$ & p-value \\
\hline Teachers & $\begin{array}{c}04 \\
(11.6 \%)\end{array}$ & $\begin{array}{c}09 \\
(26.1 \%)\end{array}$ & $\begin{array}{c}04 \\
(11.6 \%)\end{array}$ & $\begin{array}{c}13 \\
(37.7 \%)\end{array}$ & $\begin{array}{c}05 \\
(14.5 \%)\end{array}$ & 35 & \multirow{3}{*}{2.07} & \multirow{3}{*}{.72} \\
\hline Students & $\begin{array}{c}07 \\
(09.8 \%) \\
\end{array}$ & $\begin{array}{c}19 \\
(26.6 \%) \\
\end{array}$ & $\begin{array}{c}03 \\
(04.2 \%) \\
\end{array}$ & $\begin{array}{c}29 \\
(40.6 \%) \\
\end{array}$ & $\begin{array}{c}12 \\
(16.8 \%) \\
\end{array}$ & 70 & & \\
\hline Total & 11 & 28 & 07 & 42 & 17 & 105 & & \\
\hline
\end{tabular}

Non-Significant $(p>0.05) \quad$ df $=4$

table value $\chi^{2}$ at 0.05 level $=9.488$

Table 13 elaborates that the calculated value of $\chi^{2}$ was found to be 2.07 which is statistically non-significant as it is less than the critical table value of $\chi^{2}$ at 0.05 level. It unambiguously shows that both teachers and students possess similar opinions about the statement. They both disagreed to the statement "Examination system is encouraging for students with special needs".

Table 14: Overcrowded classrooms are the cause of restricted mobility for the students with special needs.

\begin{tabular}{|c|c|c|c|c|c|c|c|c|}
\hline Respondents & $\mathbf{S A}$ & $\mathbf{A}$ & UD & DA & SDA & Total & $\chi^{2}$ & p-value \\
\hline Teachers & $\begin{array}{c}09 \\
(26.1 \%)\end{array}$ & $\begin{array}{c}13 \\
(37.7 \%)\end{array}$ & $\begin{array}{c}02 \\
(05.8 \%)\end{array}$ & $\begin{array}{c}06 \\
(17.4 \%)\end{array}$ & $\begin{array}{c}05 \\
(14.5 \%)\end{array}$ & 35 & \multirow{3}{*}{0.23} & \multirow{3}{*}{.99} \\
\hline Students & $\begin{array}{c}19 \\
(26.6 \%)\end{array}$ & $\begin{array}{c}28 \\
(39.2 \%)\end{array}$ & $\begin{array}{c}03 \\
(04.2 \%)\end{array}$ & $\begin{array}{c}11 \\
(15.4 \%)\end{array}$ & $\begin{array}{c}09 \\
(12.6 \%)\end{array}$ & 70 & & \\
\hline Total & 28 & 41 & 05 & 17 & 14 & 105 & & \\
\hline
\end{tabular}


Table 14 illustrates that the computed value of $\chi^{2}$ was found to be 0.23 which is statistically non-significant as it is less than the critical table value of $\chi^{2}$ at 0.05 level. It undoubtedly indicates that both teachers and students possess the same views about the statement. They both agreed to the statement "Overcrowded classrooms are the cause of restricted mobility for the students with special needs".

Table 15: Poverty is the main obstruction in the way of education of special children.

\begin{tabular}{|c|c|c|c|c|c|c|c|c|}
\hline Respondents & SA & $\mathbf{A}$ & UD & DA & SDA & Total & $\chi^{2}$ & p-value \\
\hline Teachers & $\begin{array}{c}08 \\
(23.2 \%)\end{array}$ & $\begin{array}{c}14 \\
(40.6 \%)\end{array}$ & $\begin{array}{c}02 \\
(05.8 \%)\end{array}$ & $\begin{array}{c}08 \\
(23.2 \%)\end{array}$ & $\begin{array}{c}03 \\
(08.7 \%)\end{array}$ & 35 & \multirow{3}{*}{0.36} & \multirow{3}{*}{.99} \\
\hline Students & $\begin{array}{c}14 \\
(19.6 \%) \\
\end{array}$ & $\begin{array}{c}31 \\
(43.4 \%) \\
\end{array}$ & $\begin{array}{c}03 \\
(04.2 \%) \\
\end{array}$ & $\begin{array}{c}15 \\
(21.0 \%) \\
\end{array}$ & $\begin{array}{c}07 \\
(09.8 \%) \\
\end{array}$ & 70 & & \\
\hline Total & 22 & 45 & 05 & 23 & 10 & 105 & & \\
\hline \multicolumn{9}{|c|}{ 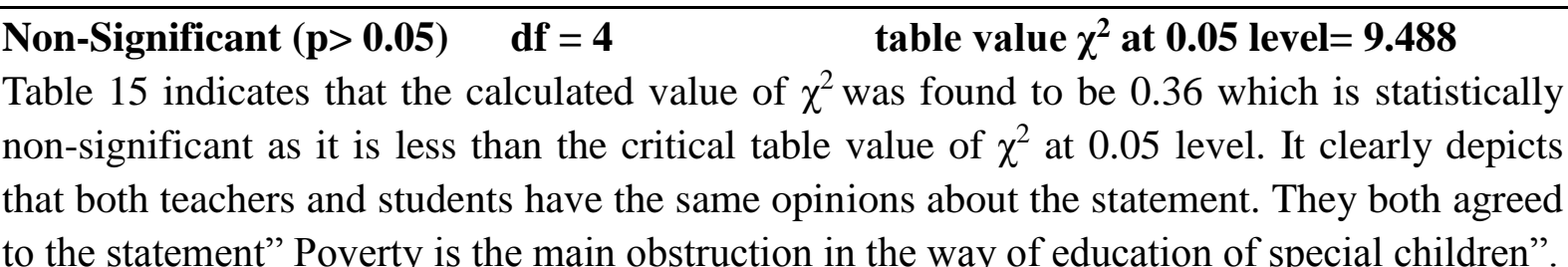 } \\
\hline
\end{tabular}

Table 16: Poor students are given scholarships for their education.

\begin{tabular}{|c|c|c|c|c|c|c|c|c|}
\hline Respondents & $\mathbf{S A}$ & $\mathbf{A}$ & UD & DA & SDA & Total & $\chi^{2}$ & p-value \\
\hline Teachers & $\begin{array}{c}07 \\
(20.3 \%)\end{array}$ & $\begin{array}{c}06 \\
(17.4 \%)\end{array}$ & $\begin{array}{c}02 \\
(05.8 \%)\end{array}$ & $\begin{array}{c}07 \\
(20.3 \%)\end{array}$ & $\begin{array}{c}13 \\
(37.7 \%)\end{array}$ & 35 & \multirow{3}{*}{0.25} & \multirow{3}{*}{.99} \\
\hline Students & $\begin{array}{c}13 \\
(18.2 \%)\end{array}$ & $\begin{array}{c}14 \\
(19.6 \%)\end{array}$ & $\begin{array}{c}05 \\
(07.0 \%)\end{array}$ & $\begin{array}{c}14 \\
(19.6 \%)\end{array}$ & $\begin{array}{c}24 \\
(33.6 \%)\end{array}$ & 70 & & \\
\hline Total & 20 & 20 & 07 & 21 & 37 & 105 & & \\
\hline
\end{tabular}

Non-Significant $(p>0.05) \quad$ df $=4 \quad$ table value $\chi^{2}$ at 0.05 level $=9.488$

Table 16 elaborates that the computed value of $\chi^{2}$ was found to be 0.25 which is statistically non-significant because it is less than the critical table value of $\chi^{2}$ at 0.05 level. It explicitly shows that both teachers and students possess the same views about the statement. They both disagreed to the statement "poor students are given scholarships for their education".

Table 17: Parents have negative attitudes about the education of special children.

\begin{tabular}{|c|c|c|c|c|c|c|c|c|}
\hline Respondents & SA & $\mathbf{A}$ & UD & DA & SDA & Total & $\chi^{2}$ & p-value \\
\hline Teachers & $\begin{array}{c}09 \\
(26.1 \%)\end{array}$ & $\begin{array}{c}16 \\
(46.4 \%)\end{array}$ & $\begin{array}{c}03 \\
(08.7 \%)\end{array}$ & $\begin{array}{c}05 \\
(14.5 \%)\end{array}$ & $\begin{array}{c}02 \\
(05.8 \%)\end{array}$ & 35 & 0.21 & .99 \\
\hline Students & 16 & 34 & 05 & 11 & 04 & 70 & & \\
\hline
\end{tabular}




\begin{tabular}{ccccccc} 
& $(22.4 \%)$ & $(47.6 \%)$ & $(07.0 \%)$ & $(15.4 \%)$ & $(05.6 \%)$ & \\
\hline Total & $\mathbf{2 5}$ & $\mathbf{5 0}$ & $\mathbf{0 8}$ & $\mathbf{1 6}$ & $\mathbf{0 7}$ & $\mathbf{1 0 5}$
\end{tabular}

Non-Significant $(p>0.05) \quad$ df $=4 \quad$ table value $\chi^{2}$ at 0.05 level $=9.488$

Table 17 indicates that the calculated value of $\chi^{2}$ was found to be 0.21 which is statistically non-significant as it is less than the critical table value of $\chi^{2}$ at 0.05 level. It obviously elaborates that both teachers and students possess the same opinions about the statement. They both agreed to the statement "Parents have negative attitudes about the education of special children".

Table 18: Special children are being taught according to Individualized Educational Programme (I.E.P).

\begin{tabular}{|c|c|c|c|c|c|c|c|c|}
\hline Respondents & $\mathbf{S A}$ & $\mathbf{A}$ & UD & DA & SDA & Total & $\chi^{2}$ & p-value \\
\hline Teachers & $\begin{array}{c}03 \\
(08.7 \%)\end{array}$ & $\begin{array}{c}06 \\
(17.4 \%)\end{array}$ & $\begin{array}{c}03 \\
(08.7 \%)\end{array}$ & $\begin{array}{c}13 \\
(37.7 \%)\end{array}$ & $\begin{array}{c}10 \\
(29.0 \%)\end{array}$ & 35 & \multirow{3}{*}{0.33} & \multirow{3}{*}{.99} \\
\hline Students & $\begin{array}{c}05 \\
(07.0 \%)\end{array}$ & $\begin{array}{c}13 \\
(18.2 \%)\end{array}$ & $\begin{array}{c}05 \\
(07.0 \%)\end{array}$ & $\begin{array}{c}29 \\
(40.6 \%)\end{array}$ & $\begin{array}{c}18 \\
(25.2 \%)\end{array}$ & 70 & & \\
\hline Total & 08 & 19 & 08 & 42 & 28 & 105 & & \\
\hline
\end{tabular}

Non-Significant $(p>0.05) \quad$ df $=4$

table value $\chi^{2}$ at 0.05 level $=9.488$

Table 18 depicts that the calculated value of $\chi^{2}$ was found to be 0.33 which is statistically non-significant as it is less than the critical table value of $\chi^{2}$ at 0.05 level. It plainly indicates that both teachers and students have the same opinions about the statement. They both disagreed to the statement "Special children are being taught according to Individualized Educational Programme (I.E.P)".

Table 19: Special children are given special attention according to their psychological needs.

\begin{tabular}{|c|c|c|c|c|c|c|c|c|}
\hline Respondents & $\mathbf{S A}$ & $\mathbf{A}$ & UD & DA & SDA & Total & $\chi^{2}$ & p-value \\
\hline Teachers & $\begin{array}{c}06 \\
(17.4 \%)\end{array}$ & $\begin{array}{c}09 \\
(26.1 \%)\end{array}$ & $\begin{array}{c}02 \\
(05.8 \%)\end{array}$ & $\begin{array}{c}11 \\
(31.9 \%)\end{array}$ & $\begin{array}{c}07 \\
(20.3 \%)\end{array}$ & 35 & \multirow{3}{*}{0.12} & \multirow{3}{*}{1.0} \\
\hline Students & $\begin{array}{c}13 \\
(18.2 \%) \\
\end{array}$ & $\begin{array}{c}16 \\
(22.4 \%) \\
\end{array}$ & $\begin{array}{c}04 \\
(05.6 \%) \\
\end{array}$ & $\begin{array}{c}23 \\
(32.2 \%) \\
\end{array}$ & $\begin{array}{c}14 \\
(19.6 \%) \\
\end{array}$ & 70 & & \\
\hline Total & 19 & 25 & 06 & 34 & 21 & 105 & & \\
\hline
\end{tabular}

Table 19 indicate that the computed value of $\chi^{2}$ was found to be 0.12 which is statistically non-significant as it is less than the critical table value of $\chi^{2}$ at 0.05 level. It clearly shows that both teachers and students have similar opinions about the statement. They both disagreed to the statement "special children are given special attention according to their psychological 
needs".

Table 20: Teachers are unaware of modern teaching aids, due to which special children have to face many difficulties.

\begin{tabular}{|c|c|c|c|c|c|c|c|c|}
\hline Respondents & SA & $\mathbf{A}$ & UD & DA & SDA & Total & $\chi^{2}$ & p-value \\
\hline Teachers & $\begin{array}{c}09 \\
(26.1 \%)\end{array}$ & $\begin{array}{c}12 \\
(34.8 \%)\end{array}$ & $\begin{array}{c}04 \\
(11.6 \%)\end{array}$ & $\begin{array}{c}06 \\
(17.4 \%)\end{array}$ & $\begin{array}{c}04 \\
(11.6 \%)\end{array}$ & 35 & & \\
\hline Students & $\begin{array}{c}20 \\
(28.0 \%) \\
\end{array}$ & $\begin{array}{c}21 \\
(29.4 \%) \\
\end{array}$ & $\begin{array}{c}03 \\
(04.2 \%) \\
\end{array}$ & $\begin{array}{c}16 \\
(22.4 \%) \\
\end{array}$ & $\begin{array}{c}10 \\
(02.9 \%) \\
\end{array}$ & 70 & 2.50 & .65 \\
\hline Total & 29 & 33 & 07 & 22 & 14 & 105 & & \\
\hline
\end{tabular}

Table 20 depicts that the calculated value of $\chi^{2}$ was found to be 2.50 which is statistically non-significant as it is less than the table value of $\chi^{2}$ at 0.05 level. It unambiguously shows that both teachers and students have similar views about the statement. They both agreed to the statement "Teachers are unaware of modern teaching aids, due to which special children have to face many difficulties".

Table 21: Toilets and drinking water facilities are arranged near to the classroom for physically handicapped children.

\begin{tabular}{|c|c|c|c|c|c|c|c|c|}
\hline Respondents & SA & $\mathbf{A}$ & UD & DA & SDA & Total & $\chi^{2}$ & p-value \\
\hline Teachers & $\begin{array}{c}03 \\
(08.7 \%)\end{array}$ & $\begin{array}{c}07 \\
(20.3 \%)\end{array}$ & $\begin{array}{c}05 \\
(14.5 \%)\end{array}$ & $\begin{array}{c}12 \\
(34.8 \%)\end{array}$ & $\begin{array}{c}06 \\
(17.4 \%)\end{array}$ & 35 & & \\
\hline Students & $\begin{array}{c}08 \\
(11.2 \%) \\
\end{array}$ & $\begin{array}{c}15 \\
(21.0 \%) \\
\end{array}$ & $\begin{array}{c}07 \\
(09.8 \%) \\
\end{array}$ & $\begin{array}{c}25 \\
(35.0 \%) \\
\end{array}$ & $\begin{array}{c}15 \\
(21.0 \%) \\
\end{array}$ & 70 & 0.75 & .95 \\
\hline Total & 11 & 22 & 12 & 37 & 21 & 105 & & \\
\hline
\end{tabular}

Table 21 depicts that the calculated value of $\chi^{2}$ was found to be 0.75 which is statistically non-significant as it is less than the critical table value of $\chi^{2}$ at 0.05 level. It plainly shows that both teachers and students have the same opinions about the statement. They both disagreed to the statement "toilet and drinking water facilities are arranged near to the classroom for special children".

\section{Analysis of Open Ended Questions}

Table 22: Problems Explained by Special Children

\begin{tabular}{lccc}
\hline Problems & Freq: & \%age & N \\
\hline Lack of basic educational facilities & 66 & $94.3 \%$ & 70 \\
Ineffective curriculum & 64 & $91.5 \%$ & 70
\end{tabular}


Lack of transport facility 2013, Vol. 3, No. 1

Lack of competent and trained teaching staff

Negative attitude of parent about special education

$87.2 \% \quad 70$

Overcrowded classrooms

Vocational training is not given to students

Table 22 illustrates the problems explained by the special children. They responded that there are various problems that affect the performance of special children. These problems were recorded as: lack of basic educational facilities; lack of transport facility; lack of competent and trained teaching staff; negative attitude of parent about special education; overcrowded classrooms; lack of facilities in public places; lack of independent work; and improper curriculum.

Table 23: Problems of Special Children Explained by Teachers

\begin{tabular}{lccc}
\hline Problems & Freq: & \%age & N \\
\hline Lack of educational facilities & 32 & $91.4 \%$ & 35 \\
Lack of in-service training & 31 & $88.7 \%$ & 35 \\
Lack of special education institutions & 30 & $85.8 \%$ & 35 \\
Teaching materials are not available & 29 & $82.9 \%$ & 35 \\
Lack of transport facility & 29 & $82.9 \%$ & 35 \\
Lack of communication between teachers and parents & 27 & $77.2 \%$ & 35 \\
Unfeasibility of building of the Special Education Institutions & 27 & $77.2 \%$ & 35 \\
Lack of trained teaching staff & 26 & $74.4 \%$ & 35 \\
Lack of well equipped library & 26 & $74.4 \%$ & 35 \\
Parents don't fulfill educational needs of special children & 26 & $74.4 \%$ & 35 \\
Majority of the children are weak & 25 & $71.5 \%$ & 35 \\
\hline
\end{tabular}

Table 23 illustrates the problems faced by special children explained by the teachers. They responded that there are various problems that are faced by special children. These problems were recorded as: lack of educational facilities; lack of in-service training for teachers; lack of special education institutions; teaching materials are not available; lack of transport facility; lack of communication between teachers and parents; unfeasibility of building of the special education institutions; lack of trained teaching staff; lack of well equipped library; and majority of the children are weak.

\section{Conclusions}

In the light of statistical analysis and findings of the study, the following conclusions were drawn:

1. The study revealed that curriculum was not designed according to the needs of special children. They were not being taught according to Individualized Educational Programme (I.E.P). Basic educational facilities, physiotherapy facility, transport 
facility, well equipped library and mobility aids were not available. Different cautionary signboards were not displayed.

2. The study also revealed that student's progress was not reviewed and evaluated monthly. Vocational training was not given to students. Teachers were not trained for teaching to physically handicapped children. Poor students were not given scholarships. There is lack of communication between teachers and parents. There is lack of institutions for special children.

3. The study also exposed that toilets and drinking water facilities were not arranged near to the classrooms for special children. In addition, school buildings were not built on feasible places. Classrooms were not arranged to provide the ease for special children. Examination system was not encouraging. Overcrowded classrooms were an obstacle for the mobility of special children. Special children were not given special attention according to their psychological needs.

4. The study also exposed that parents prefer their children without a disability over their children with disability. Parents were not found to fulfill the educational needs of their special children. Hence, special children were found in inferiority complex in society which causes their mental retardation.

\section{Recommendations}

Keeping in view the above conclusions, the researchers made some workable recommendations which are explained as under:

1. Special children should be taught through individualized educational programmes to strengthen their educational attainment.

2. As it was found that scholarships are not given to special children at the Special Education Centers therefore it is strongly recommended that special funds should be provided for poor special children to provide them uniform and other educational stationeries.

3. Student's progress should be assessed as least after a month. In this way teachers will be able to strengthen the academic performance of their students.

4. As it was revealed that the number of existing special education institutions are insufficient to cater the number of school-age special children therefore it is strongly recommended that more special education centers or institutions should be opened in the rural and urban areas to cater the requirements of special children.

5. Curriculum should be reviewed and re-designed according to the needs of the special children.

6. Transport facilities should be arranged for physically handicapped children. Toilet and drinking water facilities should be arranged near to the classrooms for physically handicapped children. In addition, recreational facilities should also be provided to the physically handicapped children in the schools.

7. To enhance the general and academic knowledge of the special children, well equipped libraries should be established in the special education centers. Different cautionary signboards should be displayed. Mobility aids i.e., crutches, wheelchairs, 
artificial limbs etc should be provided to each special education institutions. Facility for physiotherapy should be ensured in the institutions also.

8. Teachers should be provided in-service professional training at least once in a year to equip them with the modern methodologies and techniques so that they may become able to solve the educational problems of the special children effectively.

9. Researches have shown that audio visual aids or educational technologies play a crucial role in strengthening and facilitating instructional process therefore it is strongly recommended that educational technologies should be provided to each special education center and their usability should also be ensured.

10. Students with special needs feel inferiority complex in society which causes their mental retardation therefore, it is recommended that special children should be encouraged and proper concrete measures should be taken to facilitate them so that they may able to lead a happy and peaceful life.

11. The electronic and print media can play a remarkable and effective role in educating the special children. The media can also help in promoting awareness among masses to stimulate and motivate them for support. The distant learning programmes should be launched on television for educating special children.

\section{References}

Afzal, F. (1999). Provisions of Special Education in Peshawar. Unpublished M.Ed Thesis. Department of Special Education, AIOU, Islamabad. p.8

Adams, F. (1986). Special Educatio., England, Longman Group Limited. p.1

Akbar, R. M. (1989). A survey of special education facilities for the handicapped children in Pakistan. M. A Thesis, Department of Educational Planning and Management, Allama Iqbal Open University, Islamabad.

Awan, G. S. (2000). The Problems and Facilities for Physically Handicapped children. Unpublished M.Ed Thesis. Allama Iqbal Open University Islamabad.

Awan, M. (1988). Perspective of Special Education. Department Special Education Allama Iqbal Open University Islamabad.

Bregman, J. D. (1991). Current developments in the understanding of mental retardation. Part 11: Psychopathology. Journal of the American Academy of Child and Adolescent Psychiatry, 30, 861-872.

Brennan, W. (1985). Curriculum for Special Needs. Milton Keynes: The Open University Press. pp.30-31

Shah, A. A. \& Bano, M. (2002). Emotional Problems of Physically Handicapped Children in NWFP, Pakistan. Saudi Journal of Disability and Rehabilitation Vol.8, No.3. p.178

Carl, B. E. \& Leonard, H. K. (1981). Developmental/Adapted Physical

Covey, S. R. (1992). Principle-Centered Leadership. New York: Simon \& Schuster, World Health Organization, pp.27-29.

Gay, L. R. (2005). Educational research: Competencies for analysis and application. Islamabad: National Book Foundation.

Hallahan, D. P., \& Kuffman, J. M. (1978). Introduction to Learning Disabilities; A 
psycho-Behavioral Approach. Englewood Cliffs, NJ: Prentice Hall.

Hallahan, D. P., \& Kuffman, J. M. (1997). Exceptional Learners, Introduction to Special Education, 7th ed. Allyn and Bencon, USA, pp.396.

Haring N. G. \& McCormic, L. (1986). Exceptional Children and Youth. (4 ${ }^{\text {th }}$ Ed.) London, Charles E. Merrill.

Heward, W. L. (2003). Exceptional Children: An Introduction to Special Education. Columbus, OH: Merrill Publishing. p.9

Iqbal J. M. (1995). Handicapped Person in the Community. Allama Iqbal Open University, Islamabad. pp. 7-132.

Jampelal, M. B. (2004). Adjustment Problems of Hearing Impaired. New Delhi; Discovery Publishing House. p. 4

Kasonde-Ngandu, S. \& Moberg, S. (2001). Moving Towards Inclusive Education. A Baseline Study on the Special Educational Needs in the North -Western and Western Provinces of Zambia. Basic Education Sub-Sector Investment Programme BESSIP.

Kausar, T. (2008). Identification of Socialization Problems of Children with Cerebral Palsy for Classroom Adjustment. Research Report, MS Leading to Ph.D Program, Department of Special Education, Allama Iqbal Open University, Islamabad. pp.9-12

Kirl \& Callagber. (1989). Educating Exceptional Children. Houghton Mifflin Company Boston.

Luckasson, R., Coulter, D. L., Polloway, E. A., Reiss, S., Schalock, R. L., Snell, M. E., Spitalnick, D. M., \& Stark, J. A. (1992). Mental retardation: Definition, classification, and systems of supports (9th Edition). Washington, DC: American Association on Mental Retardation. p.1

Luckasson, R., Borthwick-Duffy, S., Buntinx, W. H. E., Coulter, D. L., Craig, E. M., Reeve, A., Schalock, R. L., Snell, M. E., Spitalnick, D. M., Spreat, S., \& Tasse, M. J. (2002). Mental retardation: Definition, classification, and systems of supports (10th Ed.). Washington DC: American Association on Mental Retardation. p.1

Masrur, R. (2003). Thesis writing: A systematic approach. Islamabad: Allama Iqbal Open University.

Noel, P. (2010). Physical Handicap. Social Life Journal Retrieved from. Retrieved 12th October 2010 from http://www.ehow.com/about_5220260_definition-physical-handicap.html.

Omstein, A. C., \& Levine, D. U. (1993). Foundations of Education; (5th Ed.) Boston: Houghton Mifllin. p.677

Orlansky, J. Z. (1979). Mainstreaming the Hearing Impaired Child. Mass Teaching Resources. p. 28.

Reynolds, M. C. \& Birch, J. W. (1982). Teaching Exceptional Children in American's School, Roston. VA, The Council for Exceptional Children. p.18

Roger P. \& George Giuliani, J. D. (2007). The Educator's Diagnostic Manual of Disabilities and Disorders. John Viley \& Saus, Inc. USA. p.271

Shore, K. (1986). The Special Education Handbook. New York, Teachers College Press. p. 190

William, L. H., \& Michael, D. O. (1984). Exceptional Children. Charles E. Merrill Publishing 
Company. p.18.

Yousaf, Z. \& Rabi, F. (1978). A study of educationally subnormal children in $U$. K and their implacementation for Pakistan

Ysseldyke, J. E. \& Algozzine B. (1984). Introduction to Special Education, Boston Houghton Mifflin Company. p.6

Website used:

www.cd.edb.gov.hk 